Chirurgia (2021) 116: 347-353

No. 3, May-June

Copyright@ Celsius

http://dx.doi.org/10.21614/chirurgia.116.3.347

\title{
The Effects of Ankaferd on Liver Regeneration after Partial Hepatectomy in Rats
}

\author{
Nuri Emrah Göret',Ugur Topal ${ }^{2 \star}$, Ceren Canbey Göret ${ }^{3}$, Ömer Faruk Özkan ${ }^{4}$ \\ 'Department of General Surgery, Health Sciences University, Kartal Dr Lütfi Kırdar Research and Education Hospital, Istanbul, Turkey \\ ²Department of General Surgery, Erciyes University Medical Faculty, Melikgazi, Kayseri, Turkey \\ ${ }^{3}$ Department of Surgical Pathology, Health Sciences University, Bagcilar Research and Education Hospital, Istanbul, Turkey \\ ${ }^{4}$ Department of General Surgery, Health and Science University Umraniye Training and Research Hospital, Istanbul,Turkey
}

${ }^{*}$ Corresponding author:

Ugur Topal, MD

Department of General Surgery Erciyes

University Faculty of Medicine, 38030

Melilgazi/Kayseri, Turkey

E-mail: sutopal2005@hotmail.com
Received: 03.10.2020 Accepted: 28.12 .2020

\section{Rezumat}

Efectul administrării de Ankaferd asupra regenerării hepatocitare după hepatectomie parțială la șoareci

Context: În acest studiu ne propunem să investigăm efectul hemostaticului Ankaferd posthepatectomie parțială asupra regenerării ficatului la şoareci.

Metode: Douăzeci şi patru de şoareci au fost incluşi în studiul nostru, împărțiti în trei grupuri. Grupul $\mathrm{A}=$ (Sham) 8 soareci, Grupul B = (martor) 8 şoareci, Grupul $\mathrm{C}=$ (experimental) 8 şoareci). S-a practicat excizia a două treimi din ficat în cazul tuturor şoarecilor. Şoarecilor din grupul martor li s-a administrat intraperitoneal soluție salină $0,9 \%$, iar celor din grupul experimental li $\mathrm{s}^{-a}$ administrat intraperitoneal $1 \mathrm{ml}$ Ankaferd. Şoarecii au fost sacrificați în a 7-a zi. Probele de țesut au fost prelevate din țesutul hepatic pentru evaluare histopatologică.

Rezultate: Numărul mitozelor şi scorurile de vacuolizare citoplasmatică / degenerescență hidropică au fost statistic diferite între grupuri (grupul A: 11,63 vs grupul B: 17,00 vs grupul C: 8,88 (p: 0,028) şi grupul A: 8,56 vs grupul B: 16,63 vs Grupul C: 12,31 (p: 0,034), respectiv). Scorul prezentei hepatocitelor binucleate a fost de p: 0,258 şi scorul proliferării celulare dezorganizate la nivelul parenchimului a fost: 0,076 . Nu a existat nicio diferență statistică între grupuri. Numărul mitozelor a fost p: 0116 pentru grupele A-B, p: 1,00 pentru grupele A-C şi p: 0,017 pentru grupele B-C.

Concluzii: Studiul de față nu a identificat o creştere a regenerării hepatocitare în urma administrării de Ankaferd. 
Cuvinte cheie: hepatectomie parțială, şoarece, Ankaferd, regenerare, vacuolizare citoplasmatică

\begin{abstract}
Background: In this study, we aim at investigating the effect of post partial hepatectomy Ankaferd blood stopper $(\mathrm{ABS})$ on liver regeneration in rats.

Methods: Twenty-four rats were included in our study divided into three groups. (Group A= (Sham) 8 rats, Group $\mathrm{B}=$ (control) 8 rats, Group $\mathrm{C}=$ (experimental) 8 rats). Two-thirds hepatectomy was employed in all rats. Intraperitoneal $0.9 \%$ saline was administered to the rats in the control group, and intraperitoneal $1 \mathrm{ml}$ Ankaferd was administered to the rats in the experimental group. The rats were sacrificed on the 7th day. Tissue samples were taken from the liver tissue for histopathological evaluation.

Results: The number of mitosis and the cytoplasmic vacuolization/hdyropic degeneration scores were statistically different between the groups (Group A: 11.63 vs Group B: 17.00 vs Group C: 8.88 (p:0.028) and Group A: 8.56 vs Group B: 16.63 vs Group C: 12.31 (p:0.034), respectively). The presence of binuclear hepatocytes score was p: 0.258 and disorganized distribution in cell proliferation in the parenchyma score was:0.076; There was no statistical difference between the groups. The number of mitosis was p:0116 for Group A-B, p:1.00 for Group A-C and p:0.017 for Group B-C Conclusions: Positive results indicating an increase in liver regeneration due to Ankaferd were not obtained in our study.
\end{abstract}

Key words: partial hepatectomy, rat model, Ankaferd, regeneration, cytoplasmic vacuolization

\section{Introduction}

Advancements in the field of surgery have helped us to better understand the anatomy of the liver and enabled innovations in surgical interventions. These advancements assisted in ensuring progress in liver transplantation operations as well as in resection operations. Liver regeneration has become more of an issue especially after major hepatectomy or partial liver transplantations from living donors and after the "Associating Liver Partition and Portal Vein Ligation for Staged Hepatectomy" procedure, which has been recently redefined (1).

In the light of this new procedure, surgeons have started trying new hepatectomy methods as well $(2,3)$. Agents that will increase regeneration after hepatic resection, shorten the length of treatment period, and reduce treatment expenses are still being searched for.

Although there are many agents experimented and used during the regeneration process, there is not a commonly used agent in the clinic. Experimental studies performed on animal subjects are preferred because studies relating to liver regeneration on human beings is basically difficult and risky to perform, as such, the majority of such studies are performed on rats. Effective and widely accepted new treatment strategies are required for regeneration. Our study is the first study that investigates the effects of Ankaferd on regeneration in the rat model.

Ankaferd blood stopper (ABS) was previously known as the agent that stops the bleeding by activating coagulation factors. In addition to this effect, its angiogenesis, cellular reproduction, and paracellular interaction effects are now being mentioned (4-6). Therefore, we decided to investigate the effects of Ankaferd, which, we believe, affects the postoperative regeneration in the liver, and on liver regeneration.

In the planned experiment, we aimed at injecting single dose intraperitoneal $1 \mathrm{ml}$ to 
the rats immediately after major hepatectomy and measuring the rate of histopathological regeneration by evaluating the mitotic index, binuclear hepatocyte, bile duct proliferation, central vein enlargement, disorganized distribution of cellular proliferation in the parenchyma from the sampled liver tissue after the experiment to evaluate hepatic regeneration.

\section{Methods}

\section{Experimental Protocol}

This study was performed in the laboratory of xxx Turkey, with the approval of the Laboratory Animals Ethics Committee Institutional Review Board of the University (IRB No. 2019-05 dated 15.05.2019.)

The rats were supplied from the experimental animal center at the University of Health Sciences and held in special cages under proper feeding conditions throughout the study. The rats were allowed to eat and drink freely under controlled heat (19-22 Celsius degrees) and light (from 8 a.m. to 8 p.m., dark from 8 p.m. to 8 a.m.) conditions. All rats were weighed with an analytical balance and the body weights (BW) thereof were recorded: Sprague Dawley rats that weighed between 250 and 300 gr were divided into three groups (8 rats per group).

A total of 24 rats were divided into three groups (Group $\mathrm{A}=$ (Sham) 8 rats, Group $\mathrm{B}=$ (control group) 8 rats, Group $\mathrm{C}=$ (experi ${ }^{-}$ mental group) 8 rats.

\section{Surgical Technique}

All rats were anesthetized with intramuscular (IM) ketamine (Ketalar $500 \mathrm{mg}, 35 \mathrm{mg} / \mathrm{kg}$ body weight [BW]; Pfizer) and xylazine (Kepro Xylazine 20, 15 mg/kg BW; Biopharm Animal Drugs). Laparotomy was performed on rats via a midline incision that was $2.5 \mathrm{~cm}$ in length following site clearance with povidone iodine. Hepatectomy was performed by freeing the pedicles of left anterior and median lobes and the coronary, left lateral and gastrohepatic

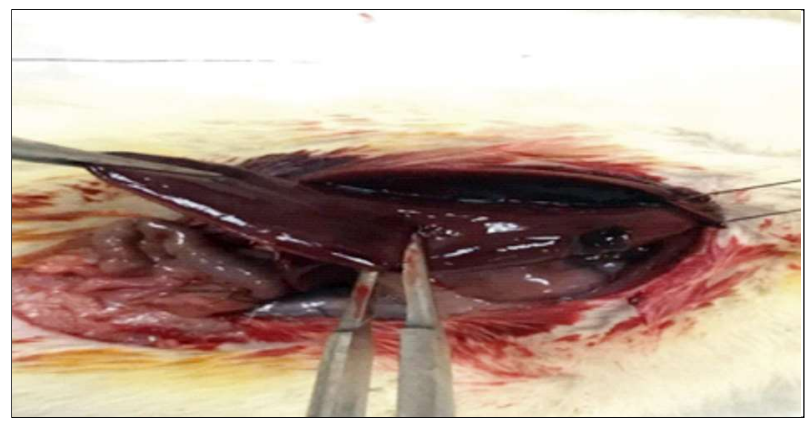

Figure 1. Partial hepatectomy procedure

ligaments according to the previously defined partial hepatectomy model and then binding them with a $4 / 0$ silk suture and cutting the suture (Fig. 1). The liver tissue that remained after the hepatectomy was checked for bleeding and congestion. Intraperitoneal $0.9 \%$ saline was administered to the rats in the control group and intraperitoneal $1 \mathrm{ml}$ Ankaferd (Ankaferd Ilac Kozmetik AS, Istanbul, Turkey) was administered to the rats in the experimental group. The midline of the abdomen was closed with two lines of continuous stitching using $4 / 0$ silk suture. The rats in all three groups were sacrificed on the $7^{\text {th }}$ day after being anesthetized with $40 \mathrm{mg} / \mathrm{kg}$ ketamine hydrochloride (HCI). Tissue samples were taken from liver tissue for histopathological evaluation (Fig. 2).

\section{Histopathological Evaluation}

Liver tissues sampled for evaluating posthepatectomy hepatic regeneration in rats

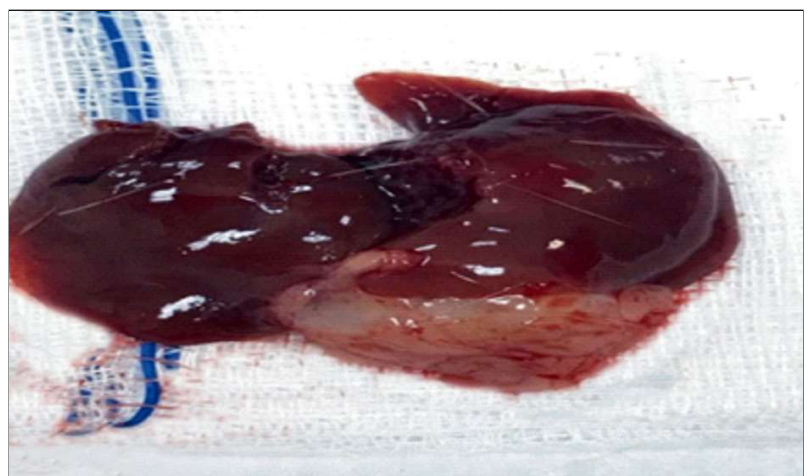

Figure 2. Macroscopic image of the regenerated liver after hepatectomy 


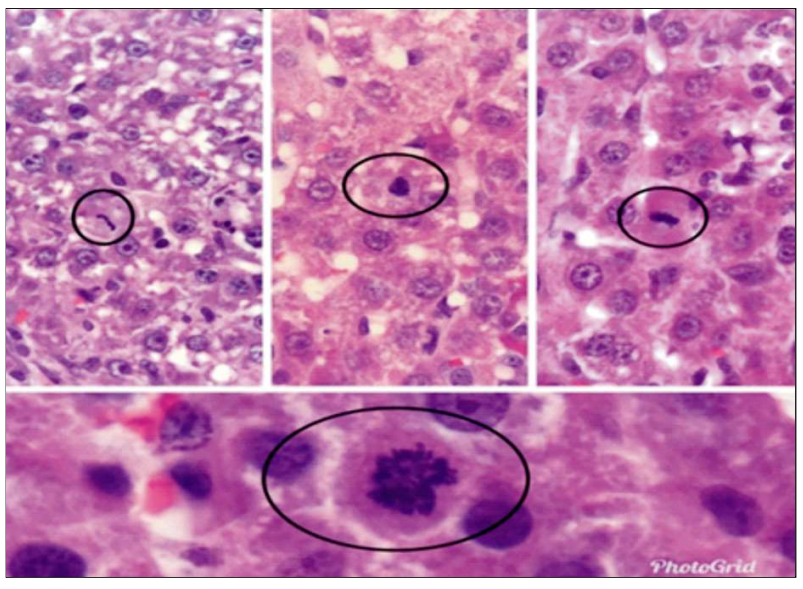

Figure 3. Mitotic figures in regenerated hepatocytes (Hematoxylin \& Eosin x 100)

were fixed with $10 \%$ buffered formaldehyde solution. Immersed in paraffin-embedded blocks, the samples were sectioned and stained with hematoxylin and eosin (H\&E). The sections were 3-4 microns thick. Histopathological effects were evaluated according to the following parameters.

- Number of mitoses;

Parts around the hepatectomized area which regenerated the most were evaluated and mitoses per 100 hepatocytes were counted (a total of 1000 hepatocytes were evaluated and mitoses were counted in 40\% Hepatic Plasma Flow.7 (Fig. 3).

- Presence of binuclear hepatocytes (Fig. d); No; Score 0

Yes (mild): Score 1

Yes (intense) Score 2

- Bile duct proliferation (Fig. 5);

No; Score 0

Yes (mild): Score 1

Yes (Intense): Score 2

- Enlargement of central veins (Fig. 6);

No: Score 0

Yes (mild): Score 1

Yes (intense): Score 2

- Disorganized distribution of cell proliferation in the parenchyma;

No; Score 0

Yes (mild): Score 2

Yes (intense): Score 2

- Cytoplasmic vacuolization/ hydropic degeneration

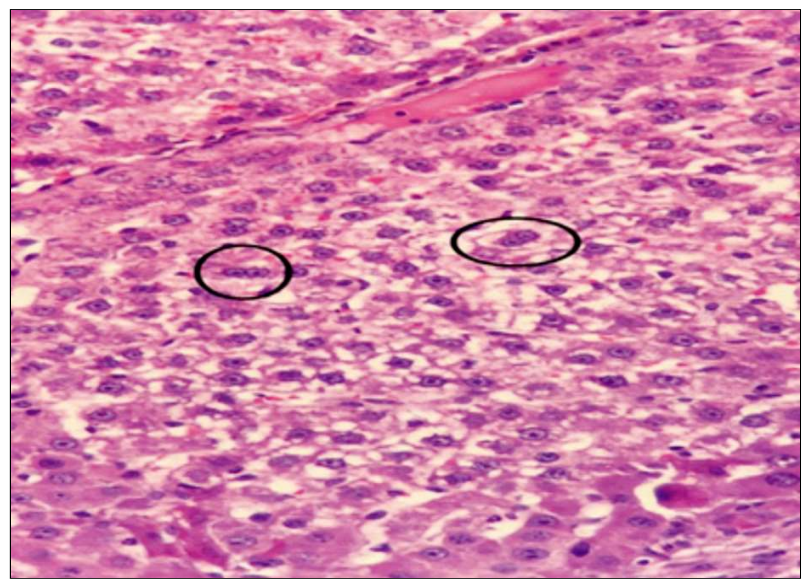

Figure 4. Binuclear hepatocytes in the regenerated liver

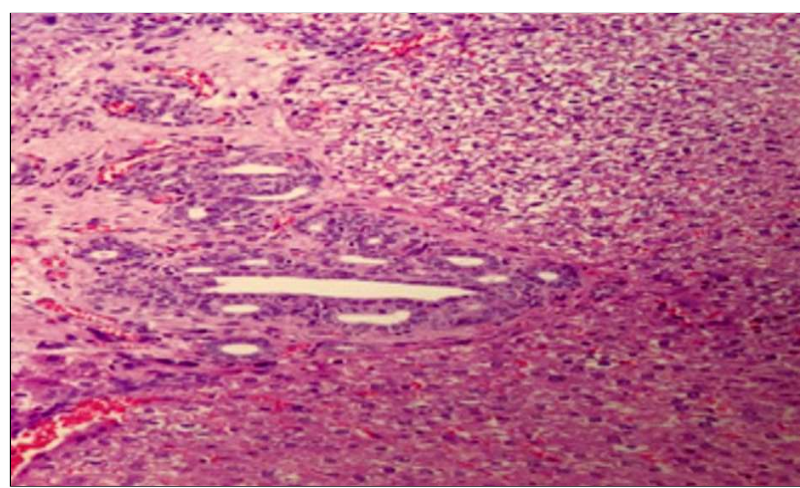

Figure 5. Intense bile duct proliferation in the regenerated liver

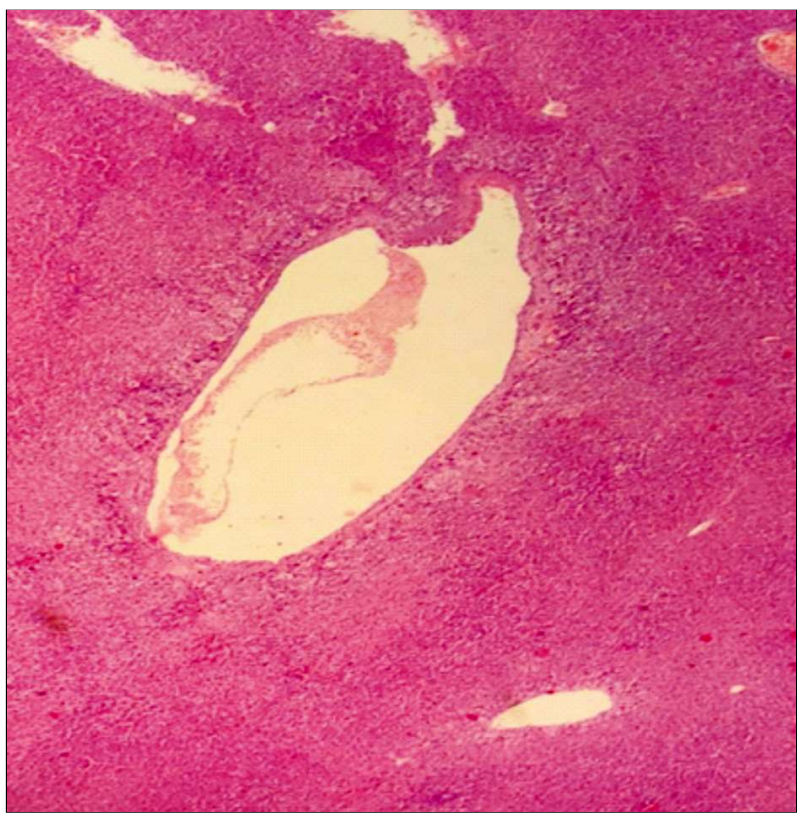

Figure 6. Enlargement of central veins in a regenerated liver 
No; Score 0

Yes (mild): Score 1

Yes (intense): Score 2

- Infiltration of leukocyte with polymorphic nuclei around the hepatectomized area;

No; Score 0

Yes (mild): Score 1

Yes (intense): Score 2

\section{Statistical Analysis}

SPSS (Statistical Package for the Social Sciences) 23.0 package software was used in the statistical analysis of data. Categorical measurements were summarized in numbers and percentages and continuous measurements were summarized as mean and standard deviation (mean and minimummaximum where necessary). Shapiro-Wilk test was employed to identify whether the parameters in the study displayed a normal distribution. Distributions were checked during the comparison of continuous measurements between the groups, and the KruskalWallis test was employed due to the fact that the parameters did not display normal distribution. The Bonferroni method, which is one of the Post Hoc analyses, was employed to identify the difference between the groups. The value of 0.05 was accepted as the statistical significance level in all tests.

\section{Results}

Samples taken from test subjects were histapathologically analyzed. It was identified in the post-analysis statistical evaluation that the outcomes did not display a normal distribution in the distribution evaluation carried out with the Shapiro-Wilk test, as such an evaluation was carried out employing nonparametric tests. All results were assessed with the Kruskal-Wallis test.

Statistically different results were analyzed in subgroups within the scope of the Bonferroni correction. All results were presented in subheadings in the order specified in the MaterialMethod section.

Number of mitosis and cytoplasmic vacuolization/hdyropic degeneration scores were statistically different between the groups (Group A: 11.63 vs Group B: 17.00 vs Group C: 8.88 (p:0.028) and Group A: 8.56 vs Group B: 16.63 vs Group C: 12.31 (p:0.034), respectively). The binuclear hepatocytes presence score was p: 0.258; central vein enlargement score was $\mathrm{p}: 0.184$; disorganized distribution in cell proliferation in the parenchyma score was :0.076; infiltration leukocyte with polymorphic nuclei around the hepatectomized area score was p:0.097. There was no statistical difference between the groups. The data are shown in Table 1.

When groups were compared with each other, numbers of mitosis were p:0116 for Group A-B, p:1.00 for Group A-C and p:0.017 for Group B-C and cytoplasmic vacuolization/ hydropic degeneration scores were $\mathrm{p}: 0.022$ for Group A-B, p: 0.459 for Group A-C, and p:0.459 for Group B-C. These are shown in Table 2.

Table 1. Kruskal-Wallis test analysis

\begin{tabular}{|c|c|c|c|c|c|}
\hline & Group A & Group B & Group C & $x^{2}$ & p \\
\hline & Mean Rank & Mean Rank & Mean Rank & & \\
\hline Number of mitosis & 11.63 & 17.00 & 8.88 & 7.142 & 0.028 \\
\hline Binuclear hepatocyte presence score & 12.50 & 12.50 & 12.50 & 0.000 & 1.000 \\
\hline Bile duct proliferation score & 10.00 & 14.50 & 13.00 & 2.706 & 0.258 \\
\hline Central vein enlargement score & 10.50 & 12.0 & 15.00 & 3.389 & 0.184 \\
\hline $\begin{array}{l}\text { Disorganized distribution of cell proliferation } \\
\text { in the parenchyma score }\end{array}$ & 8.50 & 14.50 & 14.50 & 5.147 & 0.076 \\
\hline Cytoplasmic vacuolization/hydropic degeneration score & 8.56 & 16.63 & 12.31 & 6.765 & 0.034 \\
\hline $\begin{array}{l}\text { Infiltration of leukocyte with polymorphic nuclei around } \\
\text { the hepatectomized area score }\end{array}$ & 15.00 & 9.00 & 13.50 & 4.672 & 0.097 \\
\hline
\end{tabular}


Table 2. Investigation of the differences in the number of mitosis and cytoplasmic vacuolization hydropic degeneration between the groups

\begin{tabular}{lcc}
\hline Groups & Number of mitosis & $\begin{array}{c}\text { Cytoplasmic vacuolization/ } \\
\text { hydropic degeneration }\end{array}$ \\
\hline Group A-B & 0.116 & $0.022^{\star}$ \\
\hline Group A-C & 1.000 & 0.459 \\
\hline Group B-C & $0.017^{\star}$ & 0.459 \\
\hline
\end{tabular}

${ }^{\star} \mathrm{P}<0.05$, Post hoc pair-group analysis was performed using Bonferroni correction

**Group A: sham group, group B: control group, group C: experimental group.

\section{Discussion}

It was shown that the regeneration in the liver tissue that remained after partial hepatectomy started on the very first day, and that deoxyribonucleic acid (DNA) synthesis rose to maximum in the first 24-48 hours after hepatectomy. Such regeneration usually takes place in the form of lobular formation and remaining lobule enlargement (8). Enhancement of post-resection hepatic blood flow and preservation of a series of inflammatory events under control having gained importance, many studies have been carried out, but none of them has been able to come into extensive usage. Effective and widely accepted new treatment strategies are required for regeneration and studies proceed in this direction (1-3).

Known as a hemostat, Ankaferd $^{\circledR}$ (ABS: Ankaferd Blood Stopper) is a product that is derived from five different plants called thyme (Thymus vulgaris), licorice (Glycyrrhiza glabra), unripe grape (Vitis vinifera), galangal (Alpinia officinarum), and nettle (Urtica dioica). Various studies carried out with ABS so far have revealed that ABS is effective in critical bleeding in body parts. Moreover, it is understood from clinical observation-based publications that it has antibacterial, antifungal, antineoplastic, regenerative, and anti-apoptotic effects as well (9-11).

Effects of Ankaferd have been previously evaluated in many studies.

In the study in which İşler et al. formed a bone defect in the tibiae of rats; the authors examined the effects of ABS on early bone healing. In the histopathological evaluation of the tissues on the seventh day, less inflammation was observed in the group receiving ABS than in the control group and new bone growing was observed (12).

In an experimental study, Gulden et al. (13) investigated the effects of ABS on anastomosis in the colon. The authors found that hydroxyproline levels, which are the most significant indicators of anastomosis healing, were higher in the group receiving ABS to a statistically significantly level.

In the partial nephrectomy model they employed on rats, Huri et al. stated that ABS shortened partial nephrectomy and warm ischemia periods and ensured hemostasis in the group receiving ABS. They studied the effect of Ankaferd histopathologically by evaluating glomerular necrosis, acute inflammation, calcification, fibrosis, fibroblast activation, and microvascular proliferation. They reported that inflammation, fibrosis, fibroblast activation, and microvascular proliferation in the subjects was not significantly affected. Furthermore, they evaluated the absence of glomerular necrosis and calcification as a positive effect of Ankaferd on the renal tissue (14).

In their study, Topal et al. (9) indicated that ankaferd showed anti-inflammatory effects on deep second degree burn injuries, accelerated wound healing by increasing vessel counts and had positive effects on skin tissue damaged as a result of burn injury.

In the study carried out by Karakaya et al. (6) to evaluate the effect of Ankaferd on controlling bleeding from liver laceration, they compared the hemostatic effect of ABS to that of Surgicel hemostatic effect due to liver injury. Rats in the ABS and Surgicel groups survived significantly longer than the rats in the control group (p:0.0001). There was no significant difference between the ABS and surgical groups in terms of survival. ABS and Surgicel administration was observed to be associated with a significant decrease in bleeding when compared with the control group (p:0.008).

In the liver trauma presented empirically, Kalayc1 et al.15 investigated the effects of 
Ankaferd on histopathological phenomena such as hemorrhage, necrosis, fibrovascular structure, inflammatory exudate, and regeneration and reported that the histopathological scores assessing such phenomena were higher in the Ankaferd group.

In an experimental study Karaca et al. (16) investigated the effect of $\mathrm{ABS}$ on peritoneal adhesions. They found that ABS is equally effective on abdominal adhesions with saline and has no effect on postoperative adhesion formation.

In the experimental liver trauma model, Satar et al. (17) studied the effects of ABS by comparing it with Surgicel. In their study, they determined that, on the fourteenth day, the peritoneal adhesion score of the ABS group was lower than that of both the Surgicel group $(\mathrm{P}<0.05)$ and the control group $(\mathrm{P}<0.05)$. They detected more positive results in the ABS group than in the Surgicel group on the $7^{\text {th }}$ and $14^{\text {th }}$ days. All livers in the ABS group completed their regeneration processes with minimum symptoms of inflammation. They found that, in the ABS experimental liver trauma model, ABS caused more encouraging histopathological changes and fewer intraabdominal adhesions.

\section{Conclusion}

In our study, we evaluated liver regeneration after partial hepatectomy with histopathological changes and, by contrast with the literature, we could not show the regenerative character of ankaferd. Current perspective on ABS usage is to ensure hemostasis and accelerated wound healing. Randomized controlled clinical trials of ABS revealed the antihemorrhagic effect of ABS. Future controlled studies are required to show the effects of ABS on pleiotropic activities such as antineoplastic, antithrombotic, antiinflammatory, anti-infective, antifungal and antioxidative effects.

\section{Sources of Funding}

We have no supportive funding.

\section{Conflicts of Interest}

No conflicts of interest were declared.

\section{Ethical Statement}

The study was approved by the local lnstitutional Review Board No:2019;5/05 dated 15.05.2019.

\section{References}

1. Andersen KJ, Knudsen AR, Jepsen BN, Meier M, Gunnarsson APA, Jensen UB et al. A new technique for accelerated liver regeneration: An experimental study in rats. Surgery 2017;162(2):233-47.

2. Uzun MA, Koksal N, Aktas S, Gunerhan Y, Kadioglu H, Dursun N et al. The effect of ursodeoxycholic acid on liver regeneration after partial hepatectomy in rats with non-alcoholic fatty liver disease. Hepatol Res 2009;39(8):814-21.

3. Cetinkunar S, Tokgoz S, Bilgin BC, Erdem H, Aktimur R, Can S et al. The Effect of Silymarin on Hepatic Regeneration After Partial Hepatectomy: Is Silymarin Effective in Hepatic Regeneration? Int J Clin Exp Med 2015;8(2): 2578-85.

4. Guler M, Maralcan G, Kul S, Baskonus I, Yilmaz M The Efficacy of Ankaferd Blood Stopper for the Management of Bleeding Following Total Thyroidectomy J Invest Surg. 2011;24(5):205-210.

5. Taș A, Köklü S, Beyazit Y, Karaca G, Astarcı HM, Akbal E et al. Percutaneous ankaferd injection to in vivo liver tissue in comparison to ethanol in an experimental rat model. Clin Res Hepatol Gastroenterol. 2011;35(8-9):549-553.

6. Karakaya K, Ucan HB, Tascilar O, Emre AU, Cakmak GK, Irkorucu 0 et al. Evaluation of a new hemostatic agent Ankaferd Blood Stopper in experimental liver laceration. J Invest Surg. 2009;22(3):201-206

7. Cilekar M, Uysal O, Bal C, Turel S, Yılmaz S. Leptin increases mitotic index and regeneration ratio in hepatectomized rats. Med Sci Monit Basic Res. 2013; 19:279-284

8. Labrecque DR, Steele G, Fogerty S, Wilson M, Barton J. Purification and physical-chemical characterisation of hepatic stimulator substance. Hepatol 1987;7(1):100-6.

9. Topal A, Satar NYG, Cangul IT, Oktay MA, Inan K, Cecen G et al. Ankaferd blood stopper accelerates deep second degree burn wound healing in rats. Acta Veterinaria Brno. 2018;87:261-7.

10. Chopra A., Sivaraman K. Ankaferd blood stopper: A novel hemostatic agent with unique antimicrobial, antineoplastic and regenerative properties. J Res Pharm. 2019;20(5):777-784.

11. Beyazit $\mathrm{Y}$, Kurt M, Kekilli M, Goker H, Haznedaroglu IC Evaluation of hemostatic effects of Ankaferd as an alternative medicine. Altern Med Rev. 2010; 15(4):329-336.

12. Isler SC, Demircan S, Cakarer S, Cebi Z, Keskin C, Soluk M et al. Effects of folk medicinal plant extract Ankaferd Blood Stopper on early bone healing. J Appl Oral Sci 2010:18(4):409-14

13. Cancan G, Teksoz S, Aytac E, Arikan AE, Erman H, Uzun H et al.Effects of Ankaferd on Anastomotic Healing of Colon. J Invest Surg 2014;27(1):16.

14. Huri $E$, Akgul T, Ayylldz A, Ustun H, Germiyanoglu C Hemostatic role of afolkloric medicinal plant extract in a rat partial nephrectomy model: controlled experimental trial. J Urol 2009:181(5):2349-454.

15. Kalayci MU, Soylu A, Eroglu HE, Kubilay D, Sancak B, Ugurluoglu C et al. Effect of Ankaferd Blood Stopper on hemostasis and histopathological score in experimental liver injury. Bratisl Lek Listy 2010;111(4):183-8.

16. Karaca G, Aydin O, Pehlivanli F, Kocael A, Pekcici R, Duymus E et al. Effect of ankaferd blood stopper in experimental peritoneal adhesion model. Ann Surg Treat Res. 2016:90(4):213-7.

17. Satar NYG, Akkoc A, Oktay A, Topal A, Inan K. Evaluation of the hemostatic and histopathological effects of Ankaferd Blood Stopper in experimental liver injury in rats. Blood Coagul Fibrinolysis 2013;24(5):518-24. 